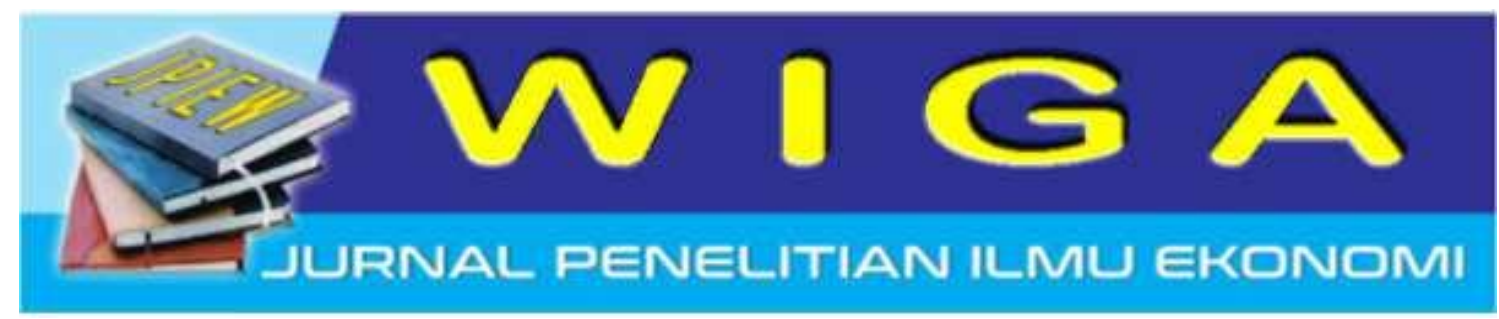

\title{
Isu Konseptual Tentang Perasaan Berkewajiban (Felt Obligation) Individu Dalam Perspektif Kerangka Pertukaran Sosial
}

\author{
Hafid Aditya Pradesa* \\ STIA LAN Bandung \\ hafid.aditya@stialanbandung.ac.id \\ Nur Imam Taufik \\ STIA LAN Bandung \\ nur.imam@stialanbandung.ac.id \\ Alikha Novira \\ STIA LAN Bandung \\ alikha.novira@stialanbandung.ac.id
}

\begin{abstract}
ABSTRAK
Teori pertukaran sosial telah menjadi landasan teoritis utama yang dapat menjelaskan fenomena hubungan antar individu dalam organisasi. Artikel ini menelaah isu konseptual dari perasaan berkewajiban (felt obligation) individu di organisasi dalam perspektif kerangka pertukaran sosial. Integrative literature review digunakan dalam artikel ini yang bertujuan untuk mengeksplorasi isu terkait definisi, konsep, faktor dan atau variabel yang terkait. Sebagai catatan penting, artikel mengungkap tentang perlunya lebih menekankan pada perspektif kerangka pertukaran sosial (social exchange) pada telaah konsep perasaan berkewajiban untuk dapat membedakan secara konseptual dengan mekanisme sikap lainnya seperti komitmen normatif. Implikasi penting tulisan ini adalah kontribusi pada perluasan pemahaman tentang konsep perasaan berkewajiban dan bagaimana hal tersebut dapat ditelaah baik secara teoritis maupun empiris.
\end{abstract}

Kata kunci: Perasaan Berkewajiban, Pertukaran Sosial, Integrative Literature Review.

\section{PENDAHULUAN}

Konsep teori utama yang digunakan dalam mengelaborasi perasaan berkewajiban individu dalam organisasi adalah teori pertukaran sosial. Teori pertukaran sosial menunjukkan asumsi klasik do ut des, yakni tentang ungkapan mengenai pola bahwa "saya memberi sesuatu supaya engkau juga memberi sesuatu kepada saya". Para ahli teoritis terkemuka antara lain adalah psikolog Blau
(1964) dan Gouldner (1960). Disadari atau tidak, pola pertukaran ini ada dan melekat dalam pola hubungan antar manusia, baik secara makro (kelompok) maupun mikro (interpersonal).

Proses pertukaran hampir terus berlanjut dalam interaksi manusia, dan tampaknya memiliki karakteristik yang khas untuk dirinya sendiri, dan untuk menghasilkan pengaruh, motivasi, dan perilaku yang tidak dapat diprediksi kecuali proses pertukaran tersebut 
dipahami. Beberapa penelitian telah mengeksplorasi peran dari perasaan berkewajiban (misalnya, Coyle-Shapiro et al., 2006; Eisenberger et al., 2001), dengan menjelaskan mengapa individu merasa berkewajiban untuk melakukan "reciprocate treatment" yang menguntungkan bagi organisasi. Bentuk resiprokasi atas perlakuan yang mendukung individu ini untuk selanjutnya dimanifestasikan dalam bentuk perilaku seperti usaha dan motivasi tambahan.

Teori pertukaran sosial yang selanjutnya menjadi fondasi awal konsep teori dukungan organisasi atau Organizational Support Theory (Eisenberger et al., 1986), yang kemudian mengkonseptualisasikan persepsi dukungan organisasi (Perceived Organizational Support atau POS). Atas dasar norma timbal balik, POS harus menciptakan perasaan kewajiban untuk peduli terhadap kesejahteraan organisasi (Eisenberger et al., 2001). Terdapat kewajiban untuk pertukaran "kepedulian" dengan bentuk "kepedulian" dari pihak lain (Foa \& Foa, 1980). Artinya jika individu merasa didukung atau dipedulikan oleh organisasi (sebagai bentuk personifikasi), maka akan terdapat bentuk balasan dukungan atau kepedulian dari individu terhadap organisasinya. Pada akhinya hal ini dapat meningkatkan komitmen afektif terhadap organisasi yang telah dipersonifikasikan oleh individu.

Sayangnya, sejak pertama kali dikenalkan oleh Eisenberger et al. (2001) dan diteliti dalam beberapa kajian empiris setelahnya, perasaan berkewajiban dipandang bukan sesuatu hal yang penting untuk ditelaah lebih mendalam. Tidak banyak penelitian yang mengulas perasaan berkewajiban dan mengintegrasikannya dalam model penelitian empiris. Oleh karena itu dipandang perlu untuk menelaah lebih lanjut mengenai konsep perasaan berkewajiban individu, termasuk dalam pola hubungannya di dalam suatu organisasi berdasarkan perspektif pertukaran sosial.

Dengan menggunakan arahan dari Torraco (2005) tentang integrative literature review, artikel ini menguji dan mengevaluasi literatur dengan tujuan untuk menjawab beberapa pertanyaan penelitian sebagai berikut :

1. Konsep atau variabel apakah yang telah matang dan terangkum dari literatur dari perasaan berkewajiban dan menunjukkan dukungan empiris yang kuat (baik sebagai anteseden maupun outcome)?

2. Bagaimana selayaknya penelitian teoritis dan empiris di masa depan dilakukan dengan berdasarkan implikasi dari artikel ini?

Dalam penelitian ini kritik atas literatur tentang perasaan berkewajiban disampaikan untuk dapat memberikan masukan dalam menguraikan arah yang lebih berarti untuk sebuah outline untuk menunjukkan telaah teoritis dan empiris di masa depan.

\section{TINJAUAN PUSTAKA}

\section{Perasaan Berkewajiban}

Konsep kewajiban (obligation), pada dasarnya mempunyai perbedaan dan beberapa kemiripan dengan konsep tugas (duty). Brandt (1964) menelaah lebih jelas tentang kedua hal tersebut untuk kemudian menyebutkan bahwa secara paradigma, fungsi "kewajiban" adalah terletak pada relasi - persetujuan dan hal retributif - relasional, sementara fungsi "tugas" terletak pada hubungan peran dalam organisasi. Tetapi generalisasi tentang penggunaan keduanya secara benar sangat sulit. "Tugas" lebih bersifat memaksa, serius dan lebih tegas. Tetapi "kewajiban" lebih mengikat kepada perasaan atau hati nurani dan standar moral personal seperti yang direfleksikan ketika kita mengatakan tentang "kewajiban yang dirasakan" (Brandt, 1964).

Neblett (1976) mengatakan bahwa perasaan berkewajiban dari seorang individu bersifat sugestif dan menarik untuk beberapa alasan, antara lain : (1) Kepercayaan tentang arti rasa berkewajiban seseorang bisa berkembang begitu baik mengingat bahwa seorang individu dapat memiliki kewajiban yang dapat mendorong untuk melakukan apa yang secara moral seseorang itu memang merasa berkewajiban untuk melakukannya dengan tidak peduli bahwa ia cenderung sebaliknya. (2) tentang perasaan seseorang bahwa ia merasa berkewajiban, lebih merupakan perasaan khas yang dihasilkan dari keinginan hati nurani untuk secara moral mengatasi bisikan non-moral lain, dan bahkan keinginan untuk menjadi tidak bermoral. Individu dapat memiliki rasa berkewajiban dapat mendorong dirinya 
melakukan apa yang secara moral wajib untuk dilakukan tidak peduli bahwa individu tersebut cenderung merasakan sebaliknya. Oleh karenanya tidaklah benar seseorang merasakan berkewajiban hanya ketika tugas dan kecenderungan sifat saling berbenturan (Neblett, 1976). Sekalipun individu yang secara moral sangat baik bukan berarti tidak pernah merasakan berkewajiban dalam melakukan aktivitas atau tindakannya. Karena sifat dari perasaan berkewajiban ini adalah lumrah atau wajar dialami oleh setiap individu (Neblett, 1976).

Secara harfiah, "felt obligation" dapat diterjemahkan sebagai "perasaan berkewajiban" (untuk selanjutnya istilah tersebut disesuaikan penggunaan dalam artikel ini). Perasaan berkewajiban mengacu pada tugas yang dirasakan oleh seorang karyawan untuk memberi nilai tambah pada organisasi sebagai imbalan atas persepsi dukungan dari organisasi (Eisenberger et al., 2001). Teori dukungan organisasi (Organizational Support Theory atau OST) menjelaskan bahwa proses ini dapat terjadi ketika seorang karyawan merasa didukung oleh organisasi (Eisenberger et al., 1986), dan kemudian merasa berhutang budi kepada organisasi makan akan mulai mencari cara untuk mengembalikan keseimbangan dalam hubungan kerja diantara karyawan-organisasi.

\section{TELAAH KRITIS}

Pencarian secara sistematis database online dilakukan dalam penelitian ini. Dengan menggunakan kata kunci yang relevan, pencarian lebih difokuskan untuk perasaan berkewajiban (felt obligation) untuk mengidentifikasi penjelajahan tentang hasil empiris yang telah dipublikasikan sebelumnya. Beberapa artikel tersebut diperlukan untuk memberikan gambaran tentang perasaan berkewajiban yang dibuat secara eksplisit (misalnya, dalam definisi operasional) atau dengan informasi cukup yang diberikan sepanjang metode abstrak, pendahuluan, hasil, dan atau bagian diskusi untuk menunjukkan dengan jelas bahwa perasaan berkewajiban adalah variabel kriteria menjadi salah satu minat dalam suatu penelitian.

Terdapat dua belas penelitian empiris terdahulu yang mengulas tentang perasaan berkewajiban yang berhasil diperoleh sebagai bahan telaah kritis dalam penelitian ini. Sebanyak lima dari dua belas penelitian empiris terdahulu tersebut tidak menguraikan secara terperinci untuk validitas konstruk dalam hal ini adalah bobot faktor untuk masing - masing indikator dari perasaan berkewajiban. Khusus untuk penelitian Coyle-Shapiro et al., (2006) mengulas tentang perasaan berkewajiban yang ditinjau pada dua konteks sampel yakni kontraktor dan klien.

Tinjauan literatur komprehensif terakhir ditawarkan oleh Kurtessis et al., (2017) dan membahas salah satu saran yang diajukan dari Baran dan Shanock (2012). Karya-karya ini mengidentifikasi kesenjangan tertutama tentang bagaimana cara perasaan berkewajiban dilihat dan dipelajari dalam perspektif pertukaran sosial. Untuk selanjutnya hal ini akan membawa kesempatan untuk memperbaiki studi tentang perasaan berkewajiban, terutama di dalam setting yang diterapkan. Sementara untuk tinjauan empiris yang telah dilakukan Rhoades dan Eisenberger (2002) tentang kajian literatur dari persepsi dukungan organisasi tidak mengulas secara mendalam tentang perasaan berkewajiban, justru lebih mengetengahkan hasil terpenting dari persepsi dukungan organisasi adalah komitmen organisasional, terutama pada komitmen organisasional afektif.

Sementara Aselage dan Eisenberger (2003) telah mengajukan proposisi tentang anteseden utama dan langsung dari persepsi dukungan organisasi yakni: (1) Perlakuan yang menyenangkan, dan (2) Kewajiban kontrak psikologis. Perlakuan yang menyenangkan dalam hubungannya dengan persepsi dukungan organisasi dimoderasi oleh kewajiban kontrak psikologis. Kewajiban kontrak psikologis sendiri dalam hubungannya dengan persepsi dukungan organisasi dimoderasi oleh penghargaan kepercayaan dari organisasi. Perasaan berkewajiban menurut Aselage dan Eisenberger (2003) memediasi hubungan diantara persepsi dukungan organisasi terhadap kinerja (sesuai dan ekstra peran) serta perilaku penarikan.

Meskipun tidak mencoba untuk meneruskan dengan ulasan dari masing - masing dekade, terdapat pemahaman bahwa kemajuan dalam satu dekade terakhir untuk telaah tentang 
perasaan berkewajiban masih dipandang kurang. Sekalipun temuan empiris sebelumnya selalu mempertimbangkan bahwa dalam konteks pertukaran sosial, perasaan berkewajiban merupakan hasil penting dari persepsi dukungan organisasi (Eisenberger et al.,2001; Liu, 2004; Coyle-Shapiro et al., 2006; Lew, 2009; Arshadi, 2011). Oleh karena itu perlunya sintesis literatur yang diperbarui untuk menyediakan pengalaman dan informasi penting serta memunculkan arah untuk penelitian masa depan.

\section{Konstruk Perasaan Berkewajiban}

Berdasarkan penelitian yang dikemukakan oleh Eisenberger et al., (2001), diuraikan enam indikator yang merefleksikan konstruk perasaan berkewajiban antara lain sebagai berikut :

1. Merasa berkewajiban melakukan aktivitas tindakan terbaik dalam pekerjaan

2. Merasa berkewajiban untuk meyakinkan hasil pekerjaan yang maksimal

3. Merasa bersalah jika tidak memenuhi standar kinerja

4. Merasa berkewajiban menggunakan jadwal pribadi

5. Merasa berkewajiban meyakinkan pelanggan

6. Merasa berkewajiban memberikan seratus persen energi

7. Merasa bahwa kewajiban adalah memenuhi persyaratan minimum dalam pekerjaan $(\mathrm{R})$

Konsep Eisenberger et al., (2001) ini yang pertama dikenali mengulas tentang perasaan berkewajiban, tentunya sebagai bentuk respirokasi dari persepsi dukungan organisasi. Dalam model penelitiannya, persepsi kewajiban memediasi persepsi dukungan organisasi dengan hasilnya seperti komitmen afektif, spontanitas organisasi, kinerja sesuai peran, serta perilaku penarikan. Peran mediasi terbesar persepsi berkewajiban terletak pada hubungan diantara persepsi dukungan organisasi terhadap komitmen afektif.

Tabel 1 Mapping Empiris Validitas Konstruk Perasaan Berkewajiban

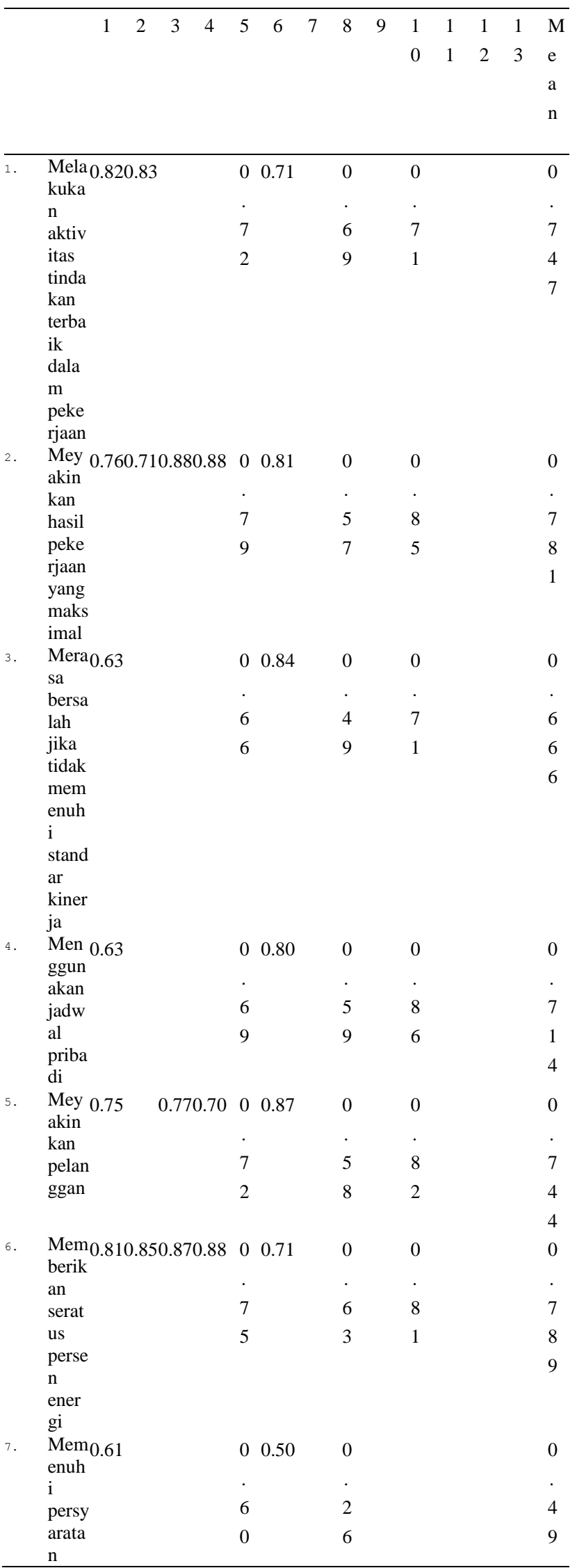

WIGA : Jurnal Penelitian IImu Ekonomi, Volume 8 Nomor 1 | 4 


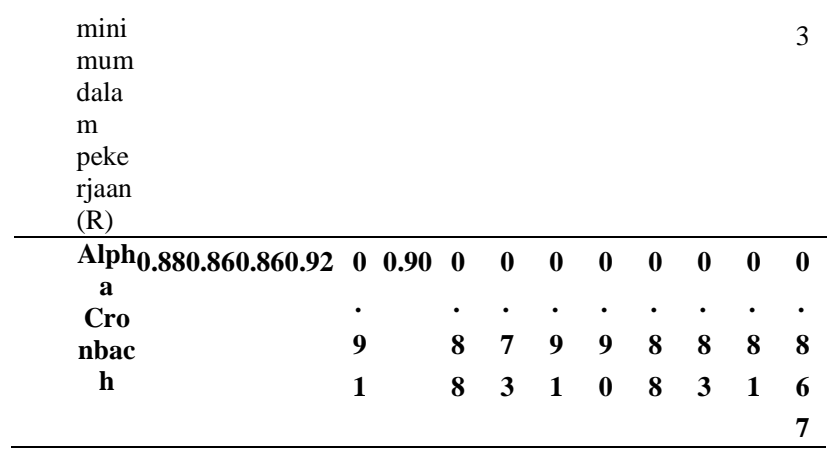

Keterangan :

1. Eisenberger et al.,(2001); 2. Liu (2004); 3. CoyleShapiro et al., (2006) untuk sampel kontraktor; 4. CoyleShapiro et al., (2006) untuk sampel klien; 5.Ladebo (2006); 6. Lew (2009); 7.Arshadi (2011); 8. Hunter (2011); 9. Ogungbamila (2010); 10. Lew (2011); 11. Shih dan Chen (2010); 12. Yu dan Frenkel (2013); 13. Ng dan Feldman (2015)

Selanjutnya dari artikel-artikel tentang perasaan berkewajiban tersebut yang berhasil dikumpulkan, beberapa peneliti setelah Eisenberger et al., (2001) membawa pemahaman yang lain tentang konstruk perasaan berkewajiban. Sebagai contoh Coyle-Shapiro $e t$ al., (2006) menelaah perasaan berkewajiban dalam model penelitiannya dengan menggunakan tiga indikator yakni :

1. Merasa berkewajiban memberikan seratus persen energi

2. Merasa berkewajiban untuk meyakinkan hasil pekerjaan

3. Merasa berkewajiban bahwa pengguna jasa dilayani dengan baik

Coyle-Shapiro et al., (2006) mengulas pentingnya perasaan berkewajiban untuk meyakinkan hasil pekerjaan bagi individu. Sementara Liu (2004) tercatat menggunakan tiga indikator perasaan berkewajiban dari Eisenberger et al., (2001), terutama pada tiga indikator yang memiliki bobot faktor tertinggi, menunjukkan bahwa hal terpenting dari perasaan berkewajiban adalah tentang memberikan seratus persen energi bagi organisasi. Lew (2011) pada penelitiannya mencatat bahwa indikator yang terbalik (R-reserved) dalam perasaan berkewajiban tidak diikutsertakan dalam model pengukurannya. Hal ini berdasarkan temuan penelitiannya terdahulu (Lew, 2009) yang menunjukkan bobot faktor terendah untuk indikator tersebut $(\lambda=0.50)$. Temuan dari Lew (2009) tersebut diperkuat dan dikonfirmasi oleh Hunter (2011) yang mengungkap indikator reversed dari konstruk perasaan berkewajiban ditemukan tidak bermakna penting. Sementara tiga artikel empiris (Arshadi, 2011; Shih dan Chen, 2010; Ogungbamila, 2010) tidak mengungkap lebih spesifik tentang nilai validitas untuk masing masing indikator dalam konstruk persepsi berkewajiban.

Berdasarkan data yang tersedia, maka analisa mendalam dilakukan untuk mengulasi nilai bobot faktor indikator sejenis yang telah dipergunakan pada penelitian terdahulu. Bobot faktor tertinggi yang dapat merefleksikan perasaan berkewajiban adalah indikator memberikan seratus persen energi. Kemudian secara berurutan indikator selanjutnya adalah meyakinkan hasil pekerjaan yang maksimal, melakukan aktivitas tindakan terbaik dalam pekerjaan, meyakinkan pelanggan, menggunakan jadwal pribadi, serta merasa bersalah jika tidak memenuhi standar kinerja. Indikator memenuhi persyaratan minimum dalam pekerjaan (reversed code) dianggap tidak mampu merefleksikan perasaan berkewajiban individu atas organisasinya.

\section{Anteseden Dan Hasil Terkait Perasaan Berkewajiban}

Anteseden dari perasaan berkewajiban yang paling banyak dikenali adalah persepsi dukungan organisasi (perceived organizational support atau POS). Penelitian POS yang bermula saat pertama kali dikenalkan oleh Eisenberger et al., (1986) sampai pada saat tinjauan empiris pertamanya diterbitkan pada tahun 2002 (Rhoades dan Eisenberger,2002), lebih menekankan peran norma timbal balik sebagai penjelasan untuk hubungan antara POS dan hasil, termasuk perasaan berkewajiban. Hal ini dapat dimengerti, karena Blau (1964) membahas komponen sosial-emosional pertukaran sosial sebagai hal yang penting, namun oleh para peneliti setelahnya hal ini dipandang sangat erat kaitannya dengan peran perasaan berkewajiban seseorang dalam membalas perlakuan yang diteirmanya (Eisenberger et al., 1986; Eisenberger et al., 2001; Coyle-Shapiro et al., 2006).

Dalam POS berlaku norma timbal balik untuk hasilnya (outcome), yang mengarah pada 
perasaan berkewajiban untuk membantu organisasi, serta harapan bahwa peningkatan kinerja atas nama organisasi (misal Arshadi, 2011). Dengan demikian, perasaan berkewajiban telah ditemukan secara positif yang timbul dari POS, untuk selanjutnya perasaan berkewajiban terkait dengan komitmen afektif (Eisenberger et al., 2001). Coyle-Shapiro et al., (2006) menguatkan keterkaitan empiris tersebut (POS perasaan berkewajiban) pada dua sampel yang berbeda (kontraktor dan klien).

Peneliti terdahulu melaporkan bahwa hubungan positif POS dengan komitmen afektif dan kinerja sering mengasumsikan bahwa perasaan karyawan untuk berkewajiban membalas perlakuan yang diterima dari organisasi menjadi proses yang mendasar. Namun baru belakangan ini, perasaan berkewajiban telah dinilai secara langsung sebagai mediator dari hubungan POS-hasil. Konsisten dengan teori dukungan organisasi, Eisenberger et al., (2001) melaporkan bahwa perasaan berkewajiban memediasi hubungan POS dengan komitmen afektif, kinerja sesuai dan ekstra peran.

Penelitian sebelumnya (misalnya, Eisenberger, et al, 2001; Coyle-Shapiro \& Neuman, 2004; Guest 2004; Guest \& Conway, 2002) menunjukkan bahwa perasaan berkewajiban karyawan adalah prediktor kuat dari kontrak psikologis antara karyawan dengan organisasinya; komitmen karyawan di tempat kerja, kinerja sesuai peran, dan spontanitas organisasi. Perasaan berkewajiban bukan hanya fungsi faktor situasional tetapi juga perbedaan individual. Coyle-Shapiro dan Neuman (2004) menunjukkan bahwa pertukaran dan penciptaan ideologi dapat dikaitkan dengan varians tambahan dalam perasaan dan pemenuhan kewajiban karyawan. Ini menyiratkan bahwa perbedaan individu membuat karyawan bereaksi secara berbeda terhadap kewajiban organisasi dan pemenuhan kewajiban yang dirasakan dan juga berkontribusi secara berbeda terhadap hubungan organisasi dengan karyawannya (Ladebo, 2006).

\section{Isu Konseptual Perasaan Berkewajiban}

Menelaah tentang istilah "kewajiban" dan atau "perasaan kewajiban", dalam bentuk sikap maupun perasaan seseorang mengarah kepada komponen dari komitmen organisasional. Isu konseptual tentang perasaan berkewajiban dapat mengarah kepada konvergensi atas konsep dari komitmen organisasional,terutama pada dimensi normatifnya.Meyer dan Allen (1997) mendefinisikan komitmen normatif sebagai perasaan kewajiban moral untuk melanjutkan pekerjaan yang telah dilakukan, dimana nilainilai internalisasi normatif atas tugas dan kewajiban membuat individu merasa wajib untuk tetap tinggal dan mempertahankan keanggotaan dalam organisasi (Meyer \& Allen, 1991; 1997).

Sedikit mengulas tentang konsep komitmen, bahwa Gellatly et al. (2006) telah mengusulkan agar profil dominan dari komitmen dan masing - masing dimensinya (afektifnormatif-kontinuan) dicirikan oleh pola pikir yang berbeda. Dimana yang pertama (afektif) mencerminkan keterikatan emosional, yang kedua (normatif) mencerminkan rasa kewajiban moral dan yang terakhir (kontinuan) merupakan kewajiban berhutang pada organisasi. Pola pikir moral disertai dengan keinginan yang kuat untuk melakukan tindakan (misalnya, OCB) memberi keuntungan pada sasaran (misalnya, organisasi) karena itu adalah tindakan yang benar dan secara moral diharuskan untuk dilakukan. Pola pikir hutang yang harus dibayar mencerminkan rasa keharusan mengikuti tindakan yang menguntungkan bagi seseorang untuk menghindari biaya sosial karena gagal melakukannya. Sampai saat ini, keberadaan pola pikir ini telah disimpulkan dari perbedaan perilaku (Meyer dan Parfyonova, 2010). Oleh karenanya perasaan berkewajiban individu bukanlah disebabkan adanya adanya keharusan untuk membayar hutang atau kewajiban moral kepada organisasi. Perasaan berkewajiban lebih kepada sifat diskresi seseorang untuk melakukan tindakan atau usaha terbaik sebagai upaya membalas perlakuan yang diterimanya. Hal ini dikarenakan basis teoritis dari perasaan berkewajiban yang berasal dari teori pertukaran sosial serta norma resiprokal dari hubungan interpersonal manusia.

Hubungan pertukaran sendiri direpresentasikan oleh kewajiban pegawai dan majikan (pemberi kerja) yang dirasakan oleh pegawai (Shore dan Barksdale, 1998). Selain itu dengan berdasarkan kontrak psikologis, pegawai 
membentuk kepercayaan tentang tipe sumber daya tertentu yang wajib mereka sediakan untuk organisasi dan organisasi berkewajiban pula untuk mengembalikannya (Aselage dan Esienberger, 2003). Shore dan Barksdale (1998) menambahkan pula adanya keseimbangan dalam

Menariknya, dari beberapa konsep yang telah ditentukan dan digunakan dalam mengartikan perasaan berkewajiban, tidak memunculkan suatu konsensus yang jelas tentang arti dari konsep (perasaan berkewajiban) tersebut. Oleh karenanya konsep ini lebih dipandang sebagai satu bentuk sikap individu sebagai bentuk hasil resiprokasi (timbal balik) dari persepsi dukungan organisasi (Eisenberger et al., 2001; serta Aselage dan Eisenberger, 2003). Mengingat keseluruhan dari penelitian sebelumnya menelaah bahwa POS merupakan hal yang paling erat berkaitan dengan perasaan berkewajiban.Oleh karena itu identifikasi empiris mengungkap POS dianggap sebagai satu-satunya hal yang mendahului dari perasaan berkewajiban. Sesungguhnya sangat menarik untuk ditelaah lebih lanjut ketika anteseden dari POS seperti praktek sumber daya manusia (Wayne et al., 1997; Allen et al., 2003), keadilan (Moorman, Blakely dan Niehoff, 1998), dukungan atasan (Rhoades dan Eisenberger, 2002), dikaitkan dengan perasaan berkewajiban secara langsung.

Ladebo (2006) menguraikan politik dalam organisasi berpengaruh tidak langsung atas perilaku keanggotaan organisasional melalui rasa berkewajiban individu. Hasil telaah lainnya perasaan berkewajiban seseorang tidak dapat memprediksi stress dalam pekerjaan. Selanjutnya Ogungbamila (2010) secara eksplisit lebih berani dengan mengaitkan perasaan berkewajiban dengan kelelahan kerja. Bentuk keterkaitan ini diuji dalam hal korelasi untuk kemudian memprediksi kelelahan kerja individu. Semakin meningkat perasaan berkewajiban individu maka hal ini akan semakin meningkatkan kelelahan seseorang dalam pekerjaannya. Sementara Shih dan Chen (2010) mengkaji keterkaitan kontrak psikologis sebagai anteseden dari perasaan berkewajiban. Penelitian Ladebo (2006), Ogungbamila (2010), serta Shih dan Chen (2010) ini merupakan beberapa kajian tentang perasaan berkewajiban hubungan pertukaran, artinya bahwa pegawai merasakan kewajibannya sebagai pegawai dan majikan merasakan kewajibannya sebagai majikan lewat kontrak psikologis mempunyai kesamaan.

yang tidak mendasarkan pada perspektif pertukaran sosial.

\section{KESIMPULAN}

Konsep perasaan berkewajiban bermula saat Eisenberger et al., (2001) mengenalkannya dan sekaligus menguji pada model empiris, dan sejak saat itu konsep ini belum banyak dikenali dan diteliti kecuali dalam kerangka perspektif pertukaran sosial, sebagai bentuk resiprokasi dari persepsi dukungan organisasi. Dalam perkembangannya, beberapa penelitian teridentifikasi telah mencoba untuk menganalisa perasaan berkewajiban dalam perspektif teoritis yang berbeda. Shih dan Chen (2010) mengkaji perasaan berkewajiban dalam integrasinya dengan teori kontrak psikologis, Ladebo (2006) menelaah kewajiban dengan politik dalam organisasi, sedangkan Ogungbamila (2010) menjelaskan perasaan berkewajiban merupakan prediktor dari occupational burnout. Ketiga penelitian empiris tersebut membuka peluang bahwa konstruk perasaan berkewajiban tidak selalu menjadi bentuk resiprokasi utama dan baku dari persepsi dukungan organisasi.

Hasil telaah integrative literature review mengungkap bahwa konsep perasaan berkewajiban lebih direfleksikan yang terpenting mulai dari memberikan seratus persen energi untuk organisasi, sampai kepada merasa bersalah jika tidak memenuhi standar kinerja. Penggunaan konstruk perasaan berkewajiban yang lebih sesuai adalah berdasarkan urutan tersebut, yang menunjukkan perbedaan makna penting untuk setiap indikator perasaan berkewajiban sejak pertama kali dikenalkan oleh Eisenberger et al., (2001).

Penelitian ini telah memberikan bukti empiris lebih lanjut dan memvalidasi teori pertukaran sosial (Blau, 1964), teori dukungan organisasi (Eisenberger, et al., 1986; Eisenberger et al., 2001; Rhoades \& Eisenberger, 2002) dan khususnya di aspek norma timbal balik (Gouldner, 1960) untuk hubungan diantara karyawan-majikan 
(organisasi) dalam bentuk perasaan berkewajiban. Tetapi hal terpenting adalah konteks tentang perasaan berkewajiban sebagai bentuk resiprokasi persepsi dukungan organisasi tidak harus membatasi pengembangan konseptual dan integrasinya dalam suatu model penelitian.

Salah satu hal yang mungkin selama ini membatasi eksplorasi tentang perasaan berkewajiban adalah pandangan tentang kemiripan konsep dengan komitmen, terutama berkaitan dengan komitmen normatif. Karena perasaan berkewajiban selalu dipandang sebagai bentuk resiprokasi persepsi dukungan organisasi, sementara persepsi dukungan organisasi dihubungkan erat dengan komitmen terutama komitmen afektif (Eisenberger et al., 2001; Rhoades \& Eisenberger, 2002). Batasan eksplorasi ini dipandang secara tidak langsung membatasi perluasan konsep dari perasaan berkewajiban dalam kajian perilaku khususnya perilaku individu dalam organisasi.

Pemeriksaan peran mediasi dari kewajiban yang dirasakan, perlu dilakukan pada konteks lainnya dalam membantu memahami proses dimana POS mempengaruhi sikap dan perilaku karyawan. Penelitian di masa depan diharapkan dapat lebih mengeksplorasi kajian tentang perasaan berkewajiban, terutama dilakukan tidak hanya pada perspektif teori pertukaran sosial. Perasaan berkewajiban dapat ditinjau berdasarkan karakteristik pribadi, kontrak psikologis, atau anteseden dari persepsi dukungan organisasi seperti praktek sumber daya manusia, dukungan atasan, serta keadilan organisasi. Secara spesifik misalnya proses yang adil di tempat kerja (yaitu keadilan prosedural) harus dapat menunjukkan kepada karyawan bahwa organisasi tersebut melakukan sesuatu hal untuk mendukung (meskipun bukan dalam bentuk dukungan organisasi yang dirasakan), dan dengan demikian dapat menyebabkan karyawan tersebut merasakan kebutuhan untuk membalasnya (yaitu merasa berkewajiban).

Penelitian di masa depan dibutuhkan untuk memahami bagaimana mekanisme perasaan berkewajiban terbentuk. Terdapat kebutuhan khusus untuk penelitian selanjutnya yang menyelidiki peran yang dimainkan oleh persepsi berkewajiban dan komitmen normatif
Telaah tentang rata-rata bobot faktor untuk konstruk perasaan berkewajiban pada hasil-hasil empiris terdahulu telah menyiratkan perbedaan yang penting dengan komitmen normatif. Perasaan berkewajiban dapat dipandang sebagai upaya sikap maksimal dari individu untuk memberikan usahanya yang terbaik bagi organisasi. Ada ruang untuk pengembangan teori tentang perasaan berkewajiban lebih lanjut dalam lanskap kajian perilaku indvidual. Namun, implikasi praktis dari pengembangan atau peningkatan perasaan berkewajiban di organisasi nampaknya cukup jelas. Literatur berkelanjutan yang diulas di sepanjang artikel ini menyoroti jenis konstruksi perasaan berkewajiban telah menunjukkan bagaimana hubungan dengan anteseden dan konsekuensinya dapat dibangun dalam suatu kerangka konseptual. Bagaimanapun konsep perasaan berkewajiban tetap dalam keadaan evolusi lebih lanjut.

\section{REKOMENDASI}

secara bersamaan. Meskipun kedua konstruk itu bisa berupa manifestasi yang berbeda dari fenomena yang sama, temuan empiris dibutuhkan untuk dapat menunjukkan dampaknya terhadap mekanisme sikap dan perilaku individual dalam organisasi. Apakah persepsi berkewajiban lebih abstrak daripada komitmen normatif? Apakah ada lebih banyak gagasan di setiap konstruksi yang tidak diungkapkan dalam definisi tersebut? Sangat menarik untuk mengeksplorasi kekhasan antara kedua konstruk tersebut (persepsi berkewajiban dan komitmen normatif) dalam kerangka model penelitian yang sama, dengan model penelitian yang dibangun tetap melandaskan pada pertukaran sosial dan atau kontrak psikologis. Sehingga diharapkan dapat mengulas secara bersamaan perbedaan konstruk diantara keduanya sekaligus kontribusinya terhadap hasil (sikap dan perilaku) individu dalam organisasi.

Sebagaimana dibuktikan dengan tinjauan literatur ini, ada sebuah pemahaman lebih lanjut tentang kemungkinan beberapa keadaan yang terputus secara teoritis, antara pendekatan pertukaran sosial dan kontrak psikologis bahkan norma resiprokal terhadap perasaan berkewajiban dan aplikasi praktis dan utilitas dari penelitian ini. Bagaimanapun temuan atau 
simpulan dari penelitian tidak dapat meramalkan masa depan dari konsep tersebut. Sebaliknya, artikel ini berusaha mengidentifikasi area perbedaan dan kesamaan, kelemahan dan kekuatan, serta pertanyaan bagi peneliti dan praktisi untuk dipertimbangkan dalam membangun kerangka kerja tentang perasaan berkewajiban di masa depan.

\section{DAFTAR PUSTAKA}

Allen, D.G., Shore, L.M., Griffeth, R.W.(2003).The Role of Perceived Organizational Support and Supportive Human Resource Practices in the Turnover Process. Journal of Management, 29(1), 99-118.

Arshadi, N. (2011). The relationships of perceived organizational support (POS) with organizational commitment, in-role performance, and turnover intention: Mediating role of felt obligation. Procedia - Social and Behavioral Sciences 30 (2011) $1103-1108$.

Aselage, J., \& Eisenberger, R. (2003). Perceived Organizational Support and Psychological Contracts: A Theoretical Integration. Journal of Organizational Behavior : No 24, 491-509.

Baran, B.E., \& Shanock, L.R. (2012). Advancing Organizational Support Theory into the Twenty-First Century World of Work. Journal of Business Psychol (2012), 27:123-147.

Blau, P. (1964). Exchange and power in social life. New York: Wiley.

Brandt, R. B. (1964). The Concepts of Obligation and Duty. Mind Association: Mind, New Series, Vol. 73, No. 291 (Jul., 1964), pp. 374-393.

Coyle-Shapiro, J. A. M., \& Neuman, J. H. (2004). The psychological contract and individual differences: The role of exchange and creditor ideologies. Journal of Vocational Behavior, 64, 150 -164 .
Coyle-Shapiro, J.A.M., Morrow, P.C., Kessler, I. (2006).Serving Two Organizatoins : Exploring The Employment Relationship of Contracted Employees. Human Resource Management, Winter 2006, Vol. 45, No. 4, Pp. 561-583.

Eisenberger, R., Huntington, R., Hutchison, S., Sowa, D. (1986). Perceived Organizational Support. Journal of Applied Psychology, Vol 71, No 3, 500507.

Gellatly, I. R., Meyer, J. P., \& Luchak, A. A. (2006). Combined effects of the three commitment components on focal and discretionary behaviors: A test of Meyer and Herscovitch's propositions. Journal of Vocational Behavior, 69, 331-345.

Gouldner, A. W. (1960). The norm of reciprocity: A preliminary statement. American Sociological Review, 25, 161-178.

Guest, D. E. (2004). The psychology of the employment relationship: An analysis based on the psychological contract. Applied Psychology: An International Review, 53, $541-555$.

Guest, D. E., \& Conway, N. (2002). Communicating the psychological contract: An employer perspective. Human Resources Management Journal, 12, 22 - 38.

Hunter, K.H. (2011). Organizational Support and Motivation Theories: Theoretical Integration and Empirical Analysis. University of Alberta : Dissertation.

Kurtessis, J. N., Eisenberger, R., Ford, M. T., Buffardi, L. C., Stewart, K. A., \& Adis, C. S. (2017). Perceived organizational support: A meta-analytic evaluation of organizational support theory. Journal of Management, 43(6), 1854-1884.

Ladebo, O. J. (2006). Perception of organizational politics: Examination of a situational antecedent and consequences among Nigeria's extension personnel. Applied Psychology: An International Review, 55, 225 - 281. 
Lew, T.Y. (2009). The Relationships between Perceived Organizational Support, Felt Obligation, Affective Organizational Commitment and Turnover Intention of Academics working with Private Higher Educational Institutions in Malaysia. European Journal of Social Sciences, 9(1), $73-87$.

Lew, T.Y. (2011).Understanding the antecedents of affective organizational commitment and turnover intention of academics in Malaysia: The organizational support theory perspectives. African Journal of Business Management, Vol.5 (7), pp. 2551-2562.

Liu, Wei. (2004). Perceived Organizational Support : Linking Human Resource Management Practices With Important Work Outcomes. Dissertation submitted to the Faculty of the Graduate School of the University of Maryland, College Park.

Meyer, J. P., \& Allen, N. J. (1991). A threecomponent conceptualization of organizational commitment. Human Resource Management Review, 1, 6189.

Meyer, J. P., \& Allen, N. J. (1997). Commitmentin the workplace: Theory, research, and application. Thousand Oaks, CA: Sage Publications.

Meyer,J.P., Parfyonova, N.M. (2010). Normative commitment in the workplace: A theoretical analysis and re-conceptualization.Human Resource Management Review, 20 (2010) 283294.

Moorman, R. H., Blakely, G. L., \& Niehoff, B. P. (1998). Does perceived organizational support mediate the relationship between procedural justice and organizational citizenship behavior? Academy of Management Journal, 41: 351-357.
Neblett, W.(1976). Feelings of Obligation. Mind Association : Mind, New Series, Vol. 85, No. 339 (Jul., 1976), pp. 341350.

Ng, T.W.H., Feldman, D.C. (2015). Felt obligations to reciprocate to an employer, preferences for mobility across employers, and gender: Threeway interaction effects on subsequent voice behavior. Journal of Vocational Behavior, 90 (2015), 36-45.

Ogungbamila, B. (2010). Effects Of Felt Obligation On Occupational Burnout Among Employees Of Post Consolidation Banks In Akure Nigeria. IFE PsychologIA : An International Journal, Volume 18, Issue 2, Sep 2010, p. 137 - 149.

Rhoades, L., \& Eisenberger, R. (2002). Perceived Organizational Support : A Review of the Literature. Journal of Applied Psychology Vol 87, No. 4, 698 $-714$.

Rhoades, L., Eisenberger,R., \& Armeli,S. (2001). Affective Commitment to the Organization : The Contribution of Perceived Organizational Support. Journal of Applied Psychology Vol. 86, No. 5, $825-836$.

Shih, C.T., \& Chen, S.J.(2010).The Social Dilemma Perspective on Psychological Contract Fulfilment and Organizational Citizenship Behaviour. Management and Organization Review, 7:1 125-151.

Shore, L.M.,\& Coyle-Shapiro, J.A.M. (2003). Editorial new developments in the employee-organization relationship. Journal of Organizational Behavior; Aug 2003; 24, 5; pg 443 - 450.

Shore, L.M., Barksdale, K. (1998). Examining degree of balance and level of obligation in the employment relationship : a social exchange approach. Journal of Organizational Behavior 19, 731 - 744 . 
Torraco, R. J. (2005). Writing integrative literature reviews: Guidelines and examples. Human Resources Development Review, 4, 356-367.

Wayne; S.J., Shore, L.M., Liden,R.C. (1997). Perceived Organizational Support and Leader-Member Exchange : A Social Exchange Perspective. Academy of Management Journal; Vol 40 No 1, 82 -111 .

Yu, C., \& Frenkel, S.J. (2013).Explaining task performance and creativity from perceived organizational support theory: Which mechanisms are more important?. Journal of Organizational Behavior, 34, 1165-1181. 